\title{
PENGARUH KEMUDAHAN PENGGUNAAN, KEPERCAYAAN, DAN COMPUTER SELF EFFICACY TERHADAP MINAT PENGGUNAAN E- SPT DALAM PELAPORAN PAJAK
}

\author{
Izhal Rio Chandra \\ Akuntansi Universitas Negeri Yogyakarta \\ izhalrio7@gmail.com \\ Diana Rahmawati \\ Staf Pengajar Jurusan Pendidikan Akuntansi Universitas Negeri Yogyakarta
}

\begin{abstract}
Abstrak : Pengaruh Kemudahan Penggunaan, Kepercayaan, Dan Computer Self Efficacy Terhadap Minat Penggunaan E- Spt Dalam Pelaporan Pajak.Penelitian ini bertujuan untuk mengetahui: (1) Pengaruh kemudahan penggunaan terhadap minat meggunakan aplikasi E SPT. (2) Pengaruh kepercayaan terhadap minat menggunakan aplikasi E SPT. (3) Pengaruh computer self efficacy terhadap minat menggunakan aplikasi E SPT. (4) Pengaruh kemudahan penggunaan, kepercayan, computer self efficacy terhadap minat menggunakan aplikasi E SPT. Metode analisis data menggunakan uji prasyarat analisis, regresi linear sederhana dan berganda. Hasil penelitian ini menunjukkan: (1) Terdapat pengaruh positif dan signifikan Kemudahan Penggunaan terhadap Minat Penggunaan E SPT, ditunjukkan oleh nilai koefisien sebesar 0,501, signifikansi 0,000 , dan nilai t hitung 7,116. (2) Terdapat pengaruh positif dan signifikan Kepercayaan terhadap Minat Penggunaan E SPT, ditunjukkan oleh nilai koefisien sebesar 0,597, signifikansi 0,000, dan nilai t hitung 4,998. (3) Terdapat pengaruh positif dan signifikan Computer Self Efficacy terhadap Minat Penggunaan E SPT, ditunjukkan oleh nilai koefisien sebesar 0,343, signifikansi 0,046, dan nilai t hitung 2,027. (4) Terdapat pengaruh positif dan signifikan Kemudahan Penggunaan, Kepercayaan dan Computer Self Efficay terhadap Minat Penggunaan E SPT, ditunjukan oleh nilai koefisien sebesar 0,679, Adjusted R ${ }^{2}$ 0,438 dan nilai F hitung 20,518.
\end{abstract}

Kata kunci: Kemudahan Penggunaan, Kepercayaan, Computer Self Efficacy dan Minat Penggunaan E SPT.

Abstract : The Influence Of Ease Of Use, Trust, And Computer Self Efficacy Toward Interest Using E Spt Application In Tax Report. This purpose of this study was to determine: (1) The influence of Ease of Use Toward Interest Using E SPT Application. (2) The influence of Trust Toward Interest Using E SPT Application. (3) The influence of Computer Self Efficacy Toward Interest Using E SPT Application.(4) The influence of Ease of Use, Trust and Computer Self Efficacy Toward Interest Using E SPT Application. The method of data analysis used were prerequisite test, simple linear regression analysis, and doubled. The results show that: (1) Be found positive effect and significance ease of use toward interest using E SPT, showed by coefficient value 0,501, significance 0,000 , and t counted 7,116. (2) Be found positive effect and significance trust toward interest using $E$ SPT, showed by coefficient value 0,597, significance 0,000, and t counted 4,998. (3) Be found positive effect and significance computer self efficacy toward interest using E SPT, showed by coefficient value 0,343, significance 0,046, and t counted 2,027. (4) Be found positive effect and significance ease of use, trust and computer self toward interest using E SPT, showed by coefficient value 0,679, Adjusted $R^{2}$ 0,438, and F counted 20,518.

Key words: Ease of Use, Trust, Computer Self Efficacy and Interest Using E SPT. 


\section{JURNAL NOMINAL / VOLUME V NOMOR 1 / TAHUN 2016}

\section{PENDAHULUAN}

Perkembangan teknologi informasi yang terjadi saat ini sangat membantu dalam segala aktivitas pekerjaan yang dilakukan manusia. Bahkan sekarang ini manusia dalam setiap harinya membutuhkan teknologi informasi baik untuk hubungan sosial, memesan barang, jual-beli, mendaftar pekerjaan, mengerjakan tugas, dan lain sebagainya. Perkembangan teknologi informasi yang terjadi saat ini bisa berdampak positif dan berdampak negatif tergantung bagaimana pengguna dan pembuat aplikasi menggunakan perkembangan teknologi informasi yang terjadi saat ini.

Tingginya kebutuhan akan teknologi menjadikan banyak orang mulai mempelajari dan mengikuti perkembangan teknologi informasi demi mengikuti tren yang terjadi dan juga banyaknya kebutuhan akan tekhnologi yang semakin menuntut. Pemerintah dalam memanfaatkan perkembangan teknologi informasi atau komputer bertujuan untuk mempererat hubungan yang terjadi antara pemerintah dengan masyarakat dan juga mengolah datadata atau suatu informasi yang ditujukan untuk kepentingan masyarakat.

Pemerintah khususnya kementerian keuangan republik Indonesia dengan memanfaatkan teknologi informasi atau komputer membuat suatu aplikasi. Aplikasi yang dibuat oleh kementrian keuangan republik Indonesia adalah E SPT (Elektronik SPT). Berdasarkan Pasal 1 Undang-Undang Nomor 28 Tahun 2007 SPT (surat pemberitahuan tahunan) sendiri merupakan surat yang oleh wajib pajak digunakan untuk melaporkan perhitungan dan pembayaran pajak, objek pajak dan atau bukan objek pajak dan atau harta dan kewajiban, menurut peraturan perundangundangan perpajakan. Menurut Per19/PJ/2014 tentang bentuk formulir surat pemberitahuan tahunan pajak penghasilan wajib pajak orang pribadi dan wajib pajak badan terdiri dari a) Formulir 1770 (PER36/PJ/2015) diperuntukkan bagi wajib pajak orang pribadi yang mempunyai penghasilan dari usaha atau pekerjaan bebas, dari satu atau lebih pemberi kerja, yang dikenakan pph final dan atau bersifat final dan atau dalam negeri lainnya atau luar negeri. b) Formulir $\quad 1770 \mathrm{~S} \quad$ (PER-36/PJ/2015) diperuntukkan bagi wajib pajak orang pribadi yang mempunyai penghasilan dari satu atau lebih pemberi kerja; dalam negeri lainya, dan atau yang dikenakan pph final dan atau bersifat final. c) Formulir SPT 1770 SS (PER-36/PJ/2015) diperuntukkan bagi wajib pajak orang pribadi yang mempunyai penghasilan selain dari usaha dan atau pekerjaan bebas jumlah penghasilan bruto tidak lebih dari $\mathrm{Rp}$ 60.000.000,00 (enam puluh juta rupiah) setahun. d) Formulir SPT 1771 diperuntukan bagi wajib pajak badan seperti PT, CV, 


\section{JURNAL NOMINAL / VOLUME V NOMOR 1 / TAHUN 2016}

Koperasi, Yayasan, Firma, Persekutuan dan sebagainya.

E SPT merupakan data SPT wajib pajak dalam bentuk elektronik yang telah dibuat oleh direktorat jendral pajak kementrian keuangan dan dapat di download di http://www.kemenkeu.go.id. E SPT memiliki format dalam bentuk formulir yang berisikan formulir laporan pajak yang lengkap dengan aplikasi perhitungan pajak sehingga memudahkan pengguna E SPT dalam membuat dan menghitung laporan pajak. Selain keunggulan E SPT yang dapat memudahkan pengguna dalam membuat dan menghitung pajak, E SPT juga memiliki kelebihan lain yaitu E SPT bersifat paperless yang di mana E SPT tidak menggunakan kertas sebagai media pelaporan pajak. E SPT dapat membuat pengguna menghemat kertas, biaya, dan juga ruangan yang akan digunakan sebagai tempat penyimpanan dokumen laporan pajak. Keunggulan lain dari E SPT yaitu E SPT dapat digunakan atau diakses oleh wajib pajak di manapun mereka berada, hal ini dikarenakan sifat E SPT yang paperless sehingga tidak perlu kesulitan membawa berkas-berkas kertas laporan pajak.

Pengiriman E SPT dapat disebut dengan E-Filing, E-filing merupakan penyampaian suatu SPT atau penyampaian pemberitahuan perpanjangan SPT tahunan secara elektronik yang dilakukan secara online yang real time melalui website direktorat jendral pajak atau penyedia jasa aplikasi atau application service provider (ASP) (www.kemenkeu.go.id). Berdasarkan pada situs (www. bisnis.liputan6.com), direktur jendral pajak kementrian keuangan, Sigit Priadi Pramudito pernah mengungkapkan, realisasi pengguna SPT elektronik atau e-filing sudah melebihi target sebanyak 2 juta pengguna. Tercatat pada tanggal 30 Maret 2015 sudah mencapai 2,1 juta pengguna, dengan demikian pengguna E SPT sudah melebihi target sekitar 100 ribu pengguna lebih.

Berdasarkan data yang telah dipaparkan di atas terbukti bahwa aplikasi E SPT mulai diminati dan digunakan oleh para wajib pajak. Minat menggunakan E SPT merupakan keadaan di mana wajib pajak akan memperhatikan aplikasi E SPT dan menganggap E SPT suatu kebutuhan dalam pelaporan pajaknya, sehingga wajib pajak yang berminat menggunakan aplikasi E SPT kemungkinan tidak lagi memperhatikan pengisian formulir SPT secara manual.

Peneliti sebelum melakukan penelitian telah melakukan wawancara terhadap 10 orang PNS yang terdiri dari 7 orang PNS di Universitas Negeri Yogyakarta dan 3 orang PNS di Pusat Kesehatan Masyarakat (Puskesmas) Mantingan tentang minat menggunakan E SPT. Hasil menunjukan bahwa 6 orang tidak berminat menggunakan aplikasi E SPT yang disebabkan karena aplikasi E SPT merupakan suatu aplikasi 


\section{JURNAL NOMINAL / VOLUME V NOMOR 1 / TAHUN 2016}

yang masih baru dan wajib pajak sudah bertahun-tahun mengisi SPT secara manual, selain itu aplikasi E SPT membutuhkan kemampuan dalam bidang teknologi sehingga memerlukan usaha, ketakutan responden akan kerusakan file atau eror karena terkena virus, dan dalam mengisi SPT manual diisikan orang lain atau membutuhkan bantuan orang lain.

Kemudahaan penggunaan adalah salah satu faktor yang mempengaruhi wajib pajak menggunakan aplikasi E SPT dalam pelaporan pajak. Kemudahan dalam menggunakan aplikasi E SPT ini dirasakan karena E SPT menyediakan formulirformulir yang dibutuhkan wajib pajak untuk mengisi data, menghitung data dan melaporkan pajak. Wajib pajak yang menggunakan aplikasi E SPT hanya tinggal mengisi data E SPT tersebut dan nantinya aplikasi tersebut yang melakukan penjumlahan sendiri, sehingga wajib pajak tidak perlu repot-repot untuk melakukan penjumlahan dari hasil pengisian data $\mathrm{E}$ SPT. E SPT merupakan pengisian SPT yang memanfaatkan bidang teknologi, maka wajib pajak yang buta atau memiliki kemampuan yang rendah dalam bidang teknologi merasa bahwa dalam menggunakan aplikasi E SPT membutuhkan banyak usaha daripada SPT manual. Wajib pajak masih merasa pengisian SPT secara manual lebih mudah dibandingkan dengan pengisian menggunakan aplikasi E SPT.
Kepercayaan (trust) adalah suatu faktor internal yang mendorong seseorang menyakini hal yang dianggapnya benar untuk dilakukan. Kepercayaan merupakan salah satu faktor yang penting dalam menggunakan aplikasi E SPT. Karena percaya terhadap suatu hal membuat orang tersebut menerapkan, menggunakan dan menjalankan suatu hal tersebut. Keberhasilan dari aplikasi E SPT tersebut memerlukan suatu kepercayaan dari para wajib pajak, agar para wajib pajak menerapkan, menggunakan dan menjalankan aplikasi E SPT tersebut untuk pelaporan pajaknya. Pemerintah masih belum melakukan suatu tindakan yang signifikan untuk meyakinkan dan menjamin keamanan data SPT para wajib pajak yang menggunakan aplikasi E SPT tersebut, sehingga menyebabkan wajib pajak tidak menggunakan aplikasi E SPT dalam pelaporan pajak karena memiliki kepercayaan rendah terhadap aplikasi tersebut. Wajib pajak masih memiliki kekhawatiran bahwa formulir-formulir yang berada di E SPT berbeda dengan formulir SPT dan data SPT yang dilaporkan akan hilang atau rusak karena terkena suatu virus.

Computer self efficacy merupakan salah satu faktor internal yang berada dalam diri pengguna atau wajib pajak tersebut. Computer self efficacy terhadap aplikasi E SPT adalah wajib pajak yang memiliki keyakinan terhadap kemampuannya untuk 


\section{JURNAL NOMINAL / VOLUME V NOMOR 1 / TAHUN 2016}

melakukan pembuatan pelaporan pajak menggunakan aplikasi E SPT.

Pengguna aplikasi E SPT adalah mereka yang sudah memiliki Nomor Pokok Wajib Pajak (NPWP), sehingga merekalah yang merupakan wajib pajak. Wajib pajak yang menerapkan aplikasi E SPT ini diharapkan akan merasa lebih mudah, lebih aman, lebih percaya dengan pelaporan pajak mereka dan tidak akan menjadi wajib pajak yang tidak membayar pajak.

Setiap Karyawan dan Dosen suatu Perguruan tinggi wajib membayar pajak dan membuat laporan pajak. Dosen dan Karyawan merupakan salah satu pengguna SPT dalam membuat laporan pajak karena Dosen dan Karyawan memiliki tanggung jawab untuk membayar dan membuat laporan pajak tersebut, namun pada dasarnya Dosen telah memiliki tugas dan beban yang banyak seperti mengajar mahasiswa, melakukan penelitian, beban tridharma dan lain sebagainya, begitu pula dengan Karyawan yang juga memiliki tugas yang sama banyaknya, dengan begitu dosen dan karyawan tidak memiliki banyak waktu untuk mengisi SPT secara manual. Berdasarkan uraian di atas maka penulis tertarik untuk meneliti tentang "Pengaruh Kemudahan Penggunaan, Kepercayaan dan Computer Self Efficacy terhadap Minat Penggunaan E SPT dalam Pelaporan Pajak".

\section{METODE PENELITIAN}

Jenis Penelitian

Penelitian ini merupakan jenis penelitian kuantitatif asosiatif.

\section{Waktu dan Tempat Penelitian}

Penelitian ini dilaksanakan di Fakultas Ekonomi Universitas Negeri Yogyakarta. Waktu dari penelitian ini dilaksanakan pada bulan Februaru 2015 sampai Maret 2016.

\section{Target/Subjek Penelitian}

Populasi dalam penelitian ini adalah dosen dan karyawan di Fakultas Ekonomi Universitas Negeri Yogyakarta yang memiliki NPWP (Nomor Pokok Wajib Pajak). Populasi dalam penelitian ini berjumlah 86 orang.

Adapun populasi tersebut yaitu dosen dan karyawan di Fakultas Ekonomi Universtitas Negeri Yogyakarta.

\section{Prosedur}

Teknik pengumpulan data dalam penelitian ini dilakukan melalui survei dengan menggunakan angket atau kuesioner. Pengumpulan data dilakukan dengan metode distribusi langsung. Metode distribusi langsung dilakukan dengan cara mendatangi responden secara langsung ke lokasi penelitian dan menyebarkan kuesioner. 


\section{JURNAL NOMINAL / VOLUME V NOMOR 1 / TAHUN 2016}

Data, Instrumen, dan Teknik Analisis data

\section{Data dan Instrumen}

Data penelitian ini adalah data primer. Pengumpulan data dilakukan dengan menggunakan kuesioner. Kuesioner yang dipakai merupakan bentuk kuesioner tertutup yaitu kuesioner yang sudah disediakan jawaban dan responden tinggal memilih jawaban yang tersedia. Penyebaran kuesioner dilakukan dengan metode distribusi langsung. Metode distribusi langsung dilakukan dengan cara mendatangi responden secara langsung ke lokasi penelitian dan menyerahkan kuesioner.

Masing-masing variabel diukur menggunakan instrumen penelitian yang diadopsi dari penelitian sebelumnya dengan dilakukan beberapa penyesuaian. Indikator yang digunakan untuk variabel Minat Menggunakan yaitu keinginan untuk menggunakan, selalu mencoba menggunakan, dan berlanjut dimasa depan. Kemudahan Penggunaan menggunakan indikator interaksi individu dengan sistem jelas dan mudah dimengerti, tidak dibutuhkan banyak usaha untuk berinteraksi dengan sistem tersebut, sistem mudah digunakan, dan mudah mengoperasikan sistem sesuai dengan apa yang ingin individu kerjakan. Kepercayaan menggunakan indikator aplikasi dapat dipercaya, aplikasi dapat menjaga janji dan komitmen, dan adanya pemikiran untuk mempercayai, sedangkan Computer Self Efficacy menggunakan indikator magnitude, strength, dan general ability. Teknik skala pengukuran menggunakan skala pengukuran Likert dengan modifikasi dengan skala 1 sampai 4 yaitu dari SS, S, TS, dan STS.

\section{Teknik Analisis Data}

Kuesioner yang nantinya akan disebarkan kepada responden harus diuji terlebih dahulu validitas dan reliabilitasnya.

Uji coba instrumen dilakukan kepada 30 responden di luar populasi. Uji coba instrumen akan dilakukan di Dinas Sosial, Tenaga Kerja dan Transmigrasi Kota Yogyakarta. Setelah diperoleh data penelitian, dilakukan uji prasyarat analisis yang meliputi uji normalitas dan uji linieritas dan uji asumsi klasik yang meliputi uji multikolinearitas dan uji heteroskedastisitas. Metode analisis data yang digunakan adalah analisis regresi linier sederhana dan analisis regresi linier moderasi.

Pengambilan data secara primer dilakukan dengan menggunakan kuesioner, maka digunakan pengujian kualitas data dengan uji validitas dan reliabilitas. Uji validitas dan reliabilias menggunakan uji terpakai yaitu data yang digunakan untuk uji coba instrumen adalah data yang diperoleh dengan sekali uji coba dan sekaligus digunakan sebagai data dalam penelitian. 
Dengan menggunakan uji coba terpakai maka item pernyataan yang dinyatakan valid langsung digunakan untuk uji hipotesis. Setelah diperoleh data penelitian, dilakukan uji analisis deskriptif, uji prasyarat analis yang terdiri dari uji linearitas, dan uji asumsi klasik yang terdiri dari uji multikolinearitas dan uji heteroskedastisitas. Uji hipotesis dilakukan dengan menggunakan uji regresi linier sederhana dan uji analisis regresi berganda.

HASIL PENELITIAN DAN PEMBAHASAN

Data yang digunakan adalah data primer hasil kuesioner yang disebarkan kepada dosen dan karyawan di Fakultas Ekonomi Universitas Negeri Yogyakarta. Kuesioner yang disebarkan sebanyak 86 kuesioner. dan yang dapat digunakan sebanyak 76 kuesioner.

\section{Identitas Responden Penelitian}

Tabel 1. Jenis Kelamin Responden

\begin{tabular}{lll}
\hline Jenis & Frequenc & Percent \\
Kelamin & $\boldsymbol{y}$ & \\
\hline Laki- & 37 & $48,7 \%$ \\
laki & & \\
\hline Wanita & 39 & $51,3 \%$ \\
& & \\
\hline Total & 76 & $100,00 \%$
\end{tabular}

Sumber: data primer diolah, 2016
Tabel 2. Usia Responden

\begin{tabular}{lll}
\hline Usia & Frequency & Percent \\
\hline $\mathbf{2 6 - 3 5}$ & 10 & $13,2 \%$ \\
tahun & & \\
\hline $\mathbf{3 6 - 4 5}$ & 24 & $31,6 \%$ \\
tahun & & \\
\hline $\mathbf{4 6 - 5 5}$ & 29 & $38,2 \%$ \\
tahun & & \\
\hline $\mathbf{5 6 - 6 6}$ & 13 & $17,1 \%$ \\
tahun & & \\
\hline Total & 76 & $100 \%$
\end{tabular}

Sumber: data primer diolah, 2016

Tabel 3. Jabatan Responden

\begin{tabular}{lll}
\hline Jabatan & Frekuensi & $\begin{array}{l}\text { Persentas } \\
\text { e }\end{array}$ \\
\hline Dosen & 62 & $81,6 \%$ \\
\hline Karyawan & 14 & $18,4 \%$ \\
\hline Total & 76 & $100,00 \%$
\end{tabular}

Sumber: data primer diolah, 2016

Tabel 4. Sumber Informasi Responden

\begin{tabular}{lll}
\hline $\begin{array}{l}\text { Sumber } \\
\text { Informasi }\end{array}$ & Frekuensi & $\begin{array}{l}\text { Persentas } \\
\text { e }\end{array}$ \\
\hline Dosen/ & 42 & $55,3 \%$ \\
Karyawan & & \\
lain & & $17,1 \%$ \\
\hline Internet & 13 & $27,6 \%$ \\
\hline Lain-lain & 21 & $100,00 \%$ \\
\hline Total & 76 &
\end{tabular}

Sumber: data primer diolah, 2016 
Analisis Data

Tabel 5. Uji Linieritas

\begin{tabular}{lll}
\hline Hubungan & $\begin{array}{l}\text { Deviation } \\
\text { From } \\
\text { Linearity }\end{array}$ & $\begin{array}{l}\text { Keteranga } \\
\end{array}$ \\
\hline $\mathbf{X 1}-\mathbf{Y}$ & 0,749 & Linier \\
\hline $\mathbf{X 2}-\mathbf{Y}$ & 0,187 & Linier \\
\hline $\mathbf{X 3}-\mathbf{Y}$ & 0,111 & Linier
\end{tabular}

Sumber: Data primer yang diolah, 2016

Hasil uji linieritas menunjukkan bahwa Linearity memiliki nilai signifikansi lebih besar dari 0,05. Dengan demikian, hubungan antara variabel X1 dengan $\mathrm{Y}, \mathrm{X} 2$ dengan $\mathrm{Y}$, dan X3 dengan Y adalah linier.

Tabel 6. Uji Multikolinearitas

\begin{tabular}{lll}
\hline Model & \multicolumn{2}{l}{ Perhitungan } \\
\cline { 2 - 3 } & Tolerance & VIF \\
\hline $\mathbf{1}$ & \\
(Constant) & 0,628 & 1,592 \\
$\mathbf{K P}$ & 0,766 & 1,305 \\
$\mathbf{K}$ & 0,782 & 1,278 \\
$\mathbf{C S E}$ & & \\
\hline
\end{tabular}

Sumber: data primer diolah, 2016

Berdasarkan tabel tersebut menunjukkan bahwa menunjukkan bahwa semua variabel bebas mempunyai nilai tolerance di atas 0,1 dan nilai VIF di bawah 10 sehingga diantara variabel bebas tidak terjadi korelasi.
Tabel 7. Uji Heteroskedastisitas

\begin{tabular}{|c|c|c|}
\hline Variabel & $\begin{array}{l}\text { Signifi } \\
\text { Kansi }\end{array}$ & Keterangan \\
\hline $\begin{array}{l}\text { Kemudahan } \\
\text { Penggunaan }\end{array}$ & 0,798 & $\begin{array}{l}\text { Tidak terjadi } \\
\text { heteroskedast } \\
\text { isitas }\end{array}$ \\
\hline Kepercayaan & 0,444 & $\begin{array}{l}\text { Tidak terjadi } \\
\text { heteroskedast } \\
\text { isitas }\end{array}$ \\
\hline $\begin{array}{l}\text { Computer Self } \\
\text { Efficacy }\end{array}$ & 0,306 & $\begin{array}{l}\text { Tidak terjadi } \\
\text { heteroskedast } \\
\text { isitas }\end{array}$ \\
\hline
\end{tabular}

Sumber: data primer diolah, 2016

Berdasarkan tabel di atas menunjukkan bahwa seluruh variabel bebas mempunyai nilai probabilitas signifikansi lebih besar dari 0,05. Dengan demikian, hal ini dapat disimpulkan bahwa tidak terjadi heteroskedastisitas dalam model regresi

\section{Hasil Uji Hipotesis}

$\mathrm{H}_{1}$ : Terdapat pengaruh Positif dan Signifikan Kemudahan Penggunan terhadap Minat Menggunakan E SPT.

Tabel 8. Rangkuman Hasil Uji Hipotesis 1

\begin{tabular}{llll}
\hline Variabel & $\begin{array}{l}\text { Koefisien } \\
\text { regresi }\end{array}$ & $\begin{array}{l}\text { thitun } \\
\mathrm{g}\end{array}$ & Sig \\
\hline Konstanta & 11,260 & & \\
\hline X1 & 0,501 & 7,116 & 0,000 \\
\hline R $\quad \mathbf{0 , 6 3 7}$ & & \\
\hline R square $\mathbf{0} \mathbf{0 , 4 0 6}$ & & \\
\hline
\end{tabular}

Sumber: Data primer yang diolah 


\section{JURNAL NOMINAL / VOLUME V NOMOR 1 / TAHUN 2016}

Berdasarkan tabel di atas dapat dilihat bahwa nilai konstanta sebesar 11,260. Hasil tersebut dapat diartikan bahwa apabila Kemudahan Penggunaan bernilai nol, maka perubahan minat penggunaan E SPT menjadi 11,260 satuan. Koefisien regresi kemudahan penggunaan sebesar 0,501 bernilai positif yang memiliki arti bahwa setiap kenaikan kemudahan penggunaan sebesar 1 satuan akan menaikkan minat penggunaan E SPT sebesar 0,501 satuan. Hal ini juga dapat dilihat dari nilai korelasi regresi (R) yang bernilai positif antara kemudahan penggunaan dan minat penggunaan E SPT sebesar 0,637. Koefisien determinasi (R Square) sebesar 0,406 menunjukan bahwa sebesar 40,6\% variabel minat pengguaan E SPT dipengaruhi oleh variabel kemudahan penggunaan dan sisanya sebesar $59,4 \%$ dipengaruhi oleh variabel lain yang tidak diteliti pada penelitian ini.

Pada uji t, diperoleh nilai $t$ hitung sebesar 7,116 (di atas nilai t tabel yaitu 1,665) mengindikasikan bahwa variabel Kemudahan Penggunaan berpengaruh secara signifikan terhadap variabel Minat Penggunaan E SPT. Hal ini juga didukung dengan nilai signifikansi 0,000 ; karena $\mathrm{t}$ hitung > t tabel $(7,665>1,665)$, signifikansi lebih kecil dari 0,05 (sig < 5\%) dan nilai regresi mempunyai nilai positif sehingga hipotesis pertama (H1) yang menyatakan bahwa " terdapat pengaruh positif dan signifikan Kemudahan Penggunaan terhadap Minat Penggunaan E SPT dalam pelaporan pajak "diterima".

Hasil penelitian ini didukung oleh teori Davis (1989) yang menunjukan bahwa suatu persepsi kemudahan penggunaan berpengaruh terhadap penerimaan pengguna. Dalam konteks penelitian ini kemudahan penggunaan berpengaruh terhadap Minat Penggunaan E SPT. Penelitian ini juga didukung oleh penelitian sebelumnya yang dilakukan oleh Nuni Yuli W (2013) yang melakukan suatu penelitian untuk mengetahui pengaruh Kepercayaan, Perceived Ease of Use, dan Perceived Usefulness Terhadap Minat Menggunakan E-Commerce Forum Jual Beli Kaskus. Nuni Yuli W (2013) menunjukkan bahwa Perceived Ease of Use (kemudahan penggunaan) berpengaruh positif dan signifikan terhadap Minat Menggunakan $E$ Commerce Forum Jual Beli Kaskus.

$\mathrm{H}_{2}$ : Terdapat pengaruh Positif dan Signifikan Kepercayaan terhadap Minat Penggunaan E SPT

Tabel 9. Rangkuman Hasil Uji Hipotesis 2

\begin{tabular}{ll}
\hline Variabel & Koefisien thitung Sig \\
& regresi
\end{tabular}

\begin{tabular}{llll} 
Konstanta & 12,278 & & \\
\hline X2 & 0,597 & 4,998 & 0,000 \\
\hline R : 0,502 & & & \\
\hline
\end{tabular}

R square : 0,252

Sumber: data primer diolah, 2016 


\section{JURNAL NOMINAL / VOLUME V NOMOR 1 / TAHUN 2016}

Berdasarkan tabel di atas, diketahui bahwa nilai konstanta sebesar 12,278. Hasil tersebut dapat diartikan bahwa apabila Kepercayaan bernilai nol, maka perubahan minat penggunaan E SPT menjadi 12,278 satuan. Koefisien regresi kepercayaan sebesar 0,597 bernilai positif yang memiliki arti bahwa setiap kepercayaan penggunaan sebesar 1 satuan akan menaikkan minat penggunaan E SPT sebesar 0,597 satuan. Hal ini juga dapat dilihat dari nilai korelasi regresi (R) yang bernilai positif antara kepercayaan dan minat penggunaan E SPT sebesar 0,502. Koefisien determinasi ( $R$ Square) sebesar 0,252 menunjukan bahwa sebesar $25,2 \%$ variabel minat pengguaan $\mathrm{E}$ SPT dipengaruhi oleh variabel kepercayaan dan sisanya sebesar $74,8 \%$ dipengaruhi oleh variabel lain yang tidak diteliti pada penelitian ini.

Nilai t hitung sebesar 4,998 (di atas nilai t tabel yaitu 1,665) mengindikasikan bahwa variabel Kepercayaan berpengaruh secara signifikan terhadap variabel Minat Penggunaan E SPT. Hal ini juga didukung dengan nilai signifikansi 0,000 ; karena $\mathrm{t}$ hitung > t tabel $(4,998>1,665)$, signifikansi lebih kecil dari $0,05(\operatorname{sig}<5 \%)$ dan nilai regresi mempunyai nilai positif sehingga hipoteses kedua (H2) yang menyatakan bahwa " terdapat pengaruh positif dan signifikan Kepercayaan terhadap Minat Penggunaan E SPT dalam pelaporan pajak “diterima".
Hasil penelitian ini didukung oleh teori Yousafzai et al (2005) dalam Nunik Yuli W (2013) yang menyatakan dalam bertransaksi melalui e-commerce, waktu merupakan suatu hal yang dibutuhkan untuk dapat membangun kepercayaan sehingga kepercayaan dapat diidentifikasikan sebagai kunci penting untuk e-commerce. Penelitian ini juga didukung oleh penelitian sebelumnya yang dilakukan oleh Reipita Sari (2013) yang melakukan suatu penelitian untuk mengetahui Pengaruh Persepsi Kebermanfaatan, Kepercayaan, dan Computer Self Efficacy Terhadap Penggunaan E-Banking pada Mahasiswa S1 Fakultas Ekonomi Universitas Negeri Yogyakarta dan Nuni Yuli W (2013).

$\mathrm{H}_{3}$ : Terdapat pengaruh Positif dan Signifikan Computer Self Efficacy terhadap Minat Penggunaan E SPT.

Tabel 10. Rangkuman Hasil Uji Hipotesis 3

\begin{tabular}{llll}
\hline Variabel & $\begin{array}{l}\text { Koefisien } \\
\text { regresi }\end{array}$ & thitung & Sig \\
& 21,123 & & \\
\hline Konstanta & & & \\
\hline $\mathbf{X 3}$ & 0,343 & 2,027 & 0,046 \\
& & & \\
& & & \\
\hline
\end{tabular}

R : 0,229

\section{R square : 0,053}

Sumber: data primer diolah, 2016

Berdasarkan tabel di atas, diketahui bahwa nilai konstanta sebesar 21,123. Hasil tersebut dapat diartikan bahwa apabila 


\section{JURNAL NOMINAL / VOLUME V NOMOR 1 / TAHUN 2016}

Computer Self Efficacy bernilai nol, maka perubahan minat penggunaan E SPT menjadi 21,123 satuan. Koefisien regresi Computer Self Efficacy sebesar 0,343 bernilai positif yang memiliki arti bahwa setiap Computer Self Efficacy penggunaan sebesar 1 satuan akan menaikkan minat penggunaan E SPT sebesar 0,343 satuan. Hal ini juga dapat dilihat dari nilai korelasi regresi (R) yang bernilai positif antara Computer Self Efficacy dan minat penggunaan E SPT sebesar 0,229. Koefisien determinasi (R Square) sebesar 0,053 menunjukan bahwa sebesar 5,3\% variabel minat pengguaan E SPT dipengaruhi oleh variabel Computer Self Efficacy dan sisanya sebesar 94,7\% dipengaruhi oleh variabel lain yang tidak diteliti pada penelitian ini.

Nilai t hitung sebesar 2,027 (di atas nilai t tabel yaitu 1,665) mengindikasikan bahwa variabel Computer Self Efficacy berpengaruh secara signifikan terhadap variabel Minat Penggunaan E SPT. Hal ini juga didukung dengan nilai signifikansi 0,046; karena $\mathrm{t}$ hitung $>\mathrm{t}$ tabel $(2,027>1.665)$, signifikansi lebih kecil dari $0,05(\operatorname{sig}<5 \%)$ dan nilai regresi mempunyai nilai positif sehingga hipotesis ketiga $(\mathrm{H} 3)$ yang menyatakan bahwa " terdapat pengaruh positif dan signifikan Computer Self Efficacy terhadap Minat Penggunaan E SPT dalam pelaporan pajak "diterima”.

Hasil penelitian ini didukung oleh Compeau dan Hinggins (1995) dalam
Reipita Sari (2013) Computer Self Efficacy diartikan sebagai penilaian kapabilitas dan keahlian komputer seseorang untuk melakukan tugas-tugas yang berhubungan dengan teknologi informasi. Dalam konteks penelitian ini Computer Self Efficacy berpengaruh terhadap Minat Penggunaan E SPT. Penelitian ini tidak didukung oleh penelitian sebelumnya yang dilakukan oleh Reipita Sari (2013) yang melakukan suatu penelitian untuk mengetahui Pengaruh Persepsi Kebermanfaatan, Kepercayaan, dan Computer Self Efficacy Terhadap Penggunaan E-Banking pada Mahasiswa S1 Fakultas Ekonomi Universitas Negeri Yogyakarta. Reipita Sari (2013) menunjukkan bahwa Computer Self Efficacy berpengaruh positif dan tapi tidak signifikan terhadap Penggunaan E-banking pada Mahasiswa S1 Fakultas Ekonomi Universitas Negeri Yogyakarta.

$\mathrm{H}_{4}$ : Terdapat pengaruh Positif dan Signifikan Kemudahan Penggunaan, Kepercayaan, dan Computer Self Efficacy secara bersama-sama terhadap Minat Penggunaan E SPT. 
Tabel 11. Hasil Uji Regresi Berganda

\begin{tabular}{lc}
\hline Konstanta & $\mathbf{8 , 0 3 1}$ \\
\hline Koefisisen Regresi X1 & 0,436 \\
\hline Koefisisen Regresi X2 & 0,300 \\
\hline Koefisisen Regresi X3 & $-0,124$ \\
\hline Fhitung & 20,518 \\
\hline Ftabel & 3,97 \\
\hline Sig & 0,000 \\
\hline R & 0,679 \\
\hline Adjusted R Square & 0,438
\end{tabular}

Sumber: data primer diolah, 2016

Berdasarkan tabel di atas diketahui nilai konstanta sebesar 8,031. Hasil tersebut dapat diartikan bahwa apabila Kemudahan Penggunaan, Kepercayaan, dan Computer Self Efficacy secara bersama-sama bernilai nol, maka perubahan minat penggunaan $\mathrm{E}$ SPT menjadi 8,031 satuan. Koefisien regresi X1 sebesar 0,436 bernilai positif yang memiliki arti bahwa setiap kenaikan Kemudahan Penggunaan sebesar 1 satuan akan menaikkan minat penggunaan E SPT sebesar 0,436 satuan jika X2 dan X3 dianggap tetap. Koefisien regresi X2 sebesar 0,300 bernilai positif yang memiliki arti bahwa setiap kenaikan Kepercayaan sebesar 1 satuan akan menaikkan minat penggunaan E SPT sebesar 0,300 satuan jika X1 dan X3 dianggap tetap. Koefisien regresi X3 sebesar $-0,124$ bernilai negatif yang memiliki arti bahwa setiap kenaikan Computer Self
Efficacy sebesar 1 satuan akan menurunkan minat penggunaan E SPT sebesar $-0,124$ satuan jika X1 dan X2 dianggap tetap.

Berdasarkan tabel di atas, diperoleh nilai koefisien korelasi (R) sebesar 0,679. Tidak mengindikasikan tanda negatif sehingga dapat ditarik kesimpulan bahwa variabel Kemudahan Penggunaan, Kepercayaan, dan Computer Self Efficacy secara bersama-sama berpengaruh positif terhadap Minat Penggunaan E SPT dalam pelaporan pajak.

Tabel 12. Model Summary Uji Regresi Berganda

\begin{tabular}{lllll}
\hline Model & R & R Square & $\begin{array}{l}\text { Adjusted } \\
\text { R Square }\end{array}$ & $\begin{array}{l}\text { Std. Error } \\
\text { of the } \\
\end{array}$ \\
& & & Estimate \\
\hline $\mathbf{1}$ & $.679^{\mathrm{a}}$ & 0.461 & 0.438 & 2.945
\end{tabular}

a. Predictors: (Constant), CSE, K, KP

Sumber: data primer diolah, 2016

Berdasarkan hasil uji adjusted $\mathrm{R}^{2}$ pada penelitian ini diperoleh nilai nilai sebesar 0,438 . Hal ini menunjukkan bahwa minat penggunaan E SPT yang dapat dijelaskan oleh variabel Kemudahan Penggunaan, Kepercayaan, dan Computer Self Efficacy sebesar $43,8 \%$ sedangkan sisanya sebesar $56,2 \%$ dijelaskan oleh variabel lain yang tidak diteliti pada penelitian ini. Sehingga variabel-variabel independen dalam menjelaskan variasi variabel dependen amat terbatas.

Berdasarkan tabel 11 di atas diperoleh nilai $\mathrm{F}$ hitung sebesar 20,518 dan nilai $\mathrm{F}$ 
tabel 3,97 pada taraf siginifikansi 5\% maka $\mathrm{F}$ hitung $>\mathrm{F}$ tabel, sehingga Kemudahan Penggunaan, Kepercayaan, dan Computer Self Efficacy secara bersama-sama berpengaruh signifikan terhadap Minat Penggunaan E SPT.

\section{SIMPULAN DAN SARAN}

\section{Simpulan}

a. Pengujian yang dilakukan memberikan hasil yang mendukung dan menerima hipotesis 1 yaitu terdapat pengaruh positif dan signifikan Kemudahan Penggunaan terhadap Minat Penggunaan E SPT Karyawan dan Dosen FE UNY. Berdasarkan nilai koefisien regresi yang bernilai positif 0,501 , nilai korelasi regresi $(\mathrm{R})$ bernilai positif 0,637 , nilai $t$ hitung > t tabel pada taraf signifikansi $5 \%(7,116>1,665), \quad$ koefisien determinasi $\left(R^{2}\right)$ sebesar 0,406. Hal ini berarti Kemudahan Penggunaan mempengaruhi tingkat Minat Penggunaan E SPT. Semakin Tinggi Kemudahan Penggunaan, maka semakin tinggi pula Minat Penggunaan E SPT.

b. Pengujian yang dilakukan memberikan hasil yang mendukung dan menerima hipotesis 2 yaitu terdapat pengaruh positif dan signifikan Kepercayaan terhadap Minat Penggunaan E SPT Karyawan dan Dosen FE UNY. Berdasarkan nilai koefisien regresi yang bernilai positif 0,597 , nilai korelasi regresi $(\mathrm{R})$ bernilai positif 0,502 , nilai $t$ hitung > t tabel pada taraf signifikansi $5 \%(4,998>1,665), \quad$ koefisien determinasi $\left(R^{2}\right)$ sebesar 0,252. Hal ini berarti Kepercayaan mempengaruhi tingkat Minat Penggunaan E SPT. Semakin Tinggi Kepercayaan, maka semakin tinggi pula Minat Penggunaan E SPT.

c. Pengujian yang dilakukan memberikan hasil yang mendukung dan menerima hipotesis 3 yang terdapat pengaruh positif dan signifikan Computer Self Efficacy terhadap Minat Penggunaan E SPT Karyawan dan Dosen FE UNY. Berdasarkan nilai koefisien regresi yang bernilai positif 0,343 , nilai korelasi regresi $(R)$ bernilai positif 0,229 , nilai $t$ hitung > t tabel pada taraf signifikansi $5 \%(2,027>1,665), \quad$ koefisien determinasi $\left(R^{2}\right)$ sebesar 0,053. Hal ini berarti Computer Self Efficacy mempengaruhi tingkat Minat Penggunaan E SPT. Semakin Tinggi Computer Self Efficacy, maka semakin tinggi pula Minat Penggunaan E SPT.

d. Pengujian yang dilakukan memberikan hasil yang mendukung dan menerima hipotesis 4 yaitu terdapat Pengaruh positif dan signifikan Kemudahan Penggunaan, Kepercayaan dan Computer Self Efficacy secara bersama-sama terhadap Minat Penggunaan E SPT Karyawan dan Dosen FE UNY. 


\section{JURNAL NOMINAL / VOLUME V NOMOR 1 / TAHUN 2016}

Berdasarkan nilai korelasi regresi $(\mathrm{R})$ bernilai positif 0,679 , nilai $\mathrm{F}$ hitung $>\mathrm{F}$ tabel pada taraf signifikansi 5\% (20,518>3,97), Adjusted $\mathrm{R}^{2}$ sebesar 0,438. Hal ini berarti Kemudahan Penggunaan, Kepercayaan dan Computer Self Efficacy secara bersama-sama mempengaruhi tingkat Minat Penggunaan E SPT.

\section{Saran}

a. Bagi peneliti selanjutnya agar memperluas cakupan responden baik dari cakupan wilayah maupun jenis wajib pajak. Selain itu penelitian selanjutnya juga harus memilih responden yang sudah menggunakan aplikasi E SPT dalam pembuatan laporan pajaknya sehingga data dapat diambil seluruhnya.

b. Pada penelitian ini Kemudahan Penggunaan, Kepercayaan dan Computer Self Efficacy memberikan sumbangan 43,8\% terhadap Minat Penggunaan E SPT, sedangkan sianya 56,2\% dijelaskan faktor lain yang tidak diteliti dalam penelitian ini. Berdasarkan hasil tersebut diharapkan penelitian mendatang dapat menambahkan variabel lainnya yang dapat berpengaruh terhadap Minat Penggunaan E SPT, seperti kebermanfaatan dan keamanan sistem.

c. Pada penelitian ini variabel Minat Penggunaan E SPT jumlah jawaban terendah sebesar 209 yang terdapat pada item pertanyaan ke empat, yaitu wajib pajak masih merasa tidak berkeinginan untuk selalu mencoba menggunakan aplikasi E SPT sesering mungkin, berdasarkan informasi ini maka disarankan sebaiknya pemerintah jangan menghapus sistem pengisian SPT secara manual beberapa tahun kedepan. Karena para wajib pajak masih belum terbiasa dengan aplikasi E SPT yang baru beberapa tahun diluncurkan pemerintah.

d. Pada penelitian ini memberikan informasi bahwa dalam variabel Kemudahan Penggunaan jumlah jawaban terendah sebesar 193 yang terdapat pada item pertanyaan ke enam, yaitu wajib pajak masih belum bisa menggunakan aplikasi E SPT dengan baik saat pertama kali mengakses, berdasarkan informasi ini disarankan kantor pajak sesering mungkin memberikan sosialisasi dan pelatihan tentang penggunaan aplikasi E SPT pada wajib pajak.

e. Pada penelitian ini memberikan informasi bahwa dalam variabel Kepercayaan jumlah jawaban terendah sebesar 228 yang terdapat pada item pertanyaan ke tujuh, yaitu wajib pajak masih merasa belum mempercayai fasilitas-fasilitas yang ada di aplikasi E SPT, berdasarkan informasi ini disarankan kantor pajak memberikan informasi atau meyakinkan bahwa fasilitas yang berada di aplikasi E SPT dapat dipercaya saat melakukan 


\section{JURNAL NOMINAL / VOLUME V NOMOR 1 / TAHUN 2016}

sosialisasi dan pelatihan kepada para wajib pajak.

f. Pada penelitian ini memberikan informasi bahwa dalam variabel CSE jumlah jawaban terendah sebesar 164 yang terdapat pada item pertanyaan ke tiga, yaitu wajib pajak masih merasa membutuhkan bantuan seseorang apabila menemui kesulitan ketika membuat laporan pajak melalui aplikasi E SPT, berdasarkan informasi ini disarankan kantor pajak untuk meningkatkan sosialisasi tentang penggunaan aplikasi $\mathrm{E}$ SPT dan memberikan layanan bantuan ketika wajib pajak menghadapi kesulitan dalam pengisian laporan pajak.

\section{DAFTAR PUSTAKA}

Das, T. K., dan Teng, B. S. (1998). "Between Trust and Control: Developing Confidance in Partner Cooperation in Alliances". Academy of Management Review. Vol. 23, No. 3, pp. 491-512.

Davis, F. D. (1989). "Perceived Usefulness, Perceived Ease of Use, and User Acceptance of Information Technology". MIS Quarterly. Vol. 13, No. 5, pp. 319-339.

Fiki Ariyanti. (2015). Pelayanan Berjalan Biasa saat Batas Akhir Laporan SPT Pajak 2014. Diambil dari: http://bisnis.liputan6.com/read/21997 79/pengguna-spt-online-membludakwajib-pajak-susah-akses-e-filing,

Diakses pada Tanggal 15 November 2015.
Ganesa dan Shankar. (1994).

"Determinatsof Long-Time

Orientation in Buyer-Seller

Relationship". Journal of marketing. Vol. 58

Haag, S., dan Keen, P. (1996). Information Technology, Tomorrow's Advantage Today. Hommond: Mcgraw-Hill College.

Habib Hanafi, Kertahadi dan Heru Susilo. (2012). "Pengaruh Persepsi Kemanfaatan dan Persepsi Kemudahan Website UB Terhadap Sikap Pengguna dengan Pendekatan TAM". Jurnal. Universitas Brawijaya Malang.

Hornby, A. S. (1995). Oxford Advanced Learner's Dictionary of Current English. Oxford: Oxford University Press.

Imam Ghozali. (2011). Aplikasi Analisis Multivariate dengan Program IBM SPSS 19. Semarang: Badan Penerbit Universitas Diponegoro.

Irmadhani. (2012). "Pengaruh Persepsi Kebermanfaatan, Persepsi Kemudahan Penggunaan dan Computer Self Efficacy Terhadap Penggunaan Online Banking pada Mahasiswa S1 Fakultas Ekonomi Universitas Negeri Yogyakarta". Skripsi. Universitas Negeri Yogyakarta.

Jugiyanto Hartono. (2007). System Informasi Keprilakuan. Yogyakarta: Andi.

(2013). Metedologi Penelitian Bisnis Salah Kaprah dan Pengalaman-pengalaman. Yogyakarta: BPFE.

Kementrian Keuangan Indonesia. (2014). Aplikasi Elektronik E-SPT Orang Pribadi. Diakses dari: http://www.kemenkeu.go.id/Page/peny ampaian-surat-pemberitahuan-online- 
efiling, Diakses pada Tanggal 15 November 2015.

Kementrian Keuangan Indonesia. (2014). Aplikasi Perpajakan. Diakses dari: www.pajak.go.id/aplikasiperpajakanwww.pajak.go.id/aplikasiperpajakan, Diakses pada Tanggal 16 November 2015.

Liberti Pandiangan. (2008). Modernisasi dan Reformasi Pelayanan Perpajakan Berdasarkan Undang-Undang Terbaru. Jakarta: PT Elex Media Komputindo.

Martin, E. W., Brown, C. V., Dehayes, D. W., et.al. (2005). "Costumer Relationship Management". Managing Information Technology $\left(5^{\text {th }} E d\right)$. Pearson Prentice Hall. Pp.194-196.

McKeown, P. G. (2001). Information Technology and the Networked

Economy. Harcourt: Orlando.

Nunik Yuli Winayu. (2013). "Pengaruh Kepercayaan, Perceived Ease of Use dan Perceived Usefulness Terhadap Minat Menggunakan E-Commerce Forum Jual Beli Kaskus”. Skripsi. Universitas Negeri Yogyakarta.

Nur Indriantoro. (2000). "Pengaruh Computer Anxienty terhadap Keahlian Dosen dalam Penggunaan Komputer”. Jurnal akuntansi \& Auditing Indonesia. Vol. 4, No. 2.

Pavlou, P. A. (2003). "Consumer Acceptance of Electronic Commerce: Integrating Trust and Risk with the Technology Acceptance Model". International Journal of Electronic Commerce. Vol. 7.

PER-6/PJ/2009 Tentang Tata Cara Penyampaian Surat Pemberitahuan Dalam Bentuk Elektronik.
Reipita Sari. (2013). "Pengaruh Persepsi Kebermanfaatan, Kepercayaan, dan Computer Self Efficacy Terhadap Penggunaan E-Banking pada Mahasiswa S1 Fakultas Ekonomi Universitas Negeri Yogyakarta". Skripsi. Universitas Negeri Yogyakarta.

Slameto. (2010). Belajar dan Faktor-faktor yang Mempengauhinya. Jakarta: PT. Rineka Cipta.

Sri Mahasari dan Yuliani Mulyadi. (2007). "Faktor-faktor yang Mempengaruhi Minat Nasabah Menggunakan Internet Banking dengan Menggunakan Kerangka Technology Acceptance Model (TAM)". Jurnal Akuntansi dan Keuangan. Vol. 9, No. 1.

Sugiyono. (2009). Metode Penelitian Kuantitatif, Kualitatif, dan $R \& D$. Bandung: Alfabeta.

Suharsimi Arikunto. (2010). Prosedur Penelitian Suatu Pendekatan Praktik. Jakarta: Rineka Cipta.

Sutrisno Hadi. (2004). Analisis Regresi. Yogyakarta: Andi Offset.

Syaiful Bahri Djamarah. (2008). Psikologi Belajar. Jakarta: PT. Rineka Cipta.

Uma Sekaran. (2011). Research Methods for Business Metodologi Penelitian untuk Bisnis. Jakarta: Penerbit Salemba Empat.

Wilhite, S. C. (1990). "Self-Efficacy, Locus of Control, Self Assessment of Memory Ability, and Study Activities as Predictors of College Course Achievement". Journal of Educational Psychology. Vol. 82. 696-700. 